\title{
Response of spotted knapweed and grass to picloram and fertilizer combinations
}

\author{
ROGER L. SHELEY AND JAMES S. JACOBS
}

Authors are assistant professor and post-doctoral research associate, Department of Plant, Soil and Environmental Sciences, Montana State University, Bozeman, Mont. 59717.

\begin{abstract}
Spotted knapweed (Centaurea maculosa Lam.) has reduced forage production, increased soil erosion, and lowered biodiversity on millions of hectares of rangeland throughout the western United States. Objectives of this study were to quantify the interaction between picloram (4-amino-3,5,6-trichloropicolinic acid) and fertilizer on spotted knapweed density and grass yield. Four picloram rates $\left(0.0,0.14,0.28\right.$, and $\left.0.42 \mathrm{~kg} \mathrm{ha}^{-1}\right)$ and 4 fertilizer rates $\left(\mathrm{N}+\mathrm{P}: 0.0+0.0,10.5+12.2,21.1+26.4\right.$, and $\left.31.7+39.6 \mathrm{~kg} \mathrm{ha}^{-1}\right)$ were applied to 3 spotted knapweed infested rangeland sites in a factorial combination arranged in a randomized-complete-block design during the spring of 1994. Grass yield and spotted knapweed density were measured at peak standing grass crop in 1994 and 1995. Data were analyzed as a split-plot in time using analysis of variance. Picloram and fertilizer did not interact to affect either spotted knapweed density or grass yield. All picloram treatments reduced spotted knapweed density to nearly zero. By 1995 , all picloram treatments increased grass yield by an average of $1,500 \mathrm{~kg} \mathrm{ha}^{-1}$. Fertilization did not affect spotted knapweed density, but the highest rates increased grass yield on those sites with a substantial residual grass understory. Combining fertilizer with picloram may enhance grass yield on sites with a residual of highly productive grasses.
\end{abstract}

Key Words: Centaurea maculosa, spotted knapweed control, integrated weed management, forage production

In the grasslands of Montana and the Pacific Northwest, the decline of forage grasses, such as Idaho fescue (Festuca idahoensis Elmer) has been accompanied by dramatic increases in spotted knapweed (Centaurea maculosa Lam). Spotted knapweed, a deeply taprooted perennial, was introduced into North America around 1900 (Roché and Talbott 1986) and has become established in 133 counties in 5 northwestern states (Rice. 1994. Invaders data base software, Univ. of Montana, Missoula, Mont. 59812) and 2 Canadian provinces (Lacey et al. 1989). This weed has the potential to invade about $50 \%$ (20 million ha) of rangeland in Montana alone (Chicoine et al. 1985). Spotted knapweed is detrimental to soil and water resources (Lacey et al. 1989), reduces wildlife and livestock forage production (Watson and Renney 1974, Spoon et al. 1983) and lowers biodiversity (Tyser and Key 1988).

Published with the approval of the director, Montana Agricultural Experiment Station, as Journal No. 4080.

Manuscript accepted 9 Jun 1996.
Most broadleaf herbicides are effective in killing spotted knapweed, but new seedlings usually emerge within a year (Fay et al. 1989). Picloram (4-amino-3,5,6-trichloropicolinic acid) applied at a rate of $0.28 \mathrm{~kg} \mathrm{ha}^{-1}$ provides control for 2 to 5 years (Davis 1990). Although the persistence of picloram in the soil affects weeds for 12 to 30 months (Hamaker et al. 1967, Lacey 1985), extended control is enhanced by competition from residual perennial grasses that are released by the herbicide application (Hubbard 1975, Chicoine 1984, Sheley et al. 1984, Roche 1988). Although herbicide application and fertilization have increased forage production on rangelands (Dwyer and Schickendanz 1971, Hart et al. 1995), little is known about combining them to control knapweed and enhance forage production.

Integrating picloram and fertilizers may have a synergistic effect on providing spotted knapweed control and enhanced grass production. In a pilot study, Sheley and Roché (1982) combined picloram (0.28 kg ha $\mathrm{kg}^{-1}$ and fertilizer (N+P: $\left.17.9+22.4 \mathrm{~kg} \mathrm{ha}^{-1}\right)$ which increased grass yield from about 275 (control) and 660 (picloram alone) to over 2,200 (picloram plus fertilizer) $\mathrm{kg} \mathrm{ha}^{-1} 2$ years after application. In that study, knapweed control was greater where picloram was combined with fertilization.

Ranchers and other land managers need a better understanding of the potential for using picloram and fertilizer combinations to manage spotted knapweed infested rangeland. This study used a 4 (picloram rates) by 4 (fertilizer rates) factorial design at 3 sites with varying residual grass species to quantify the interaction between picloram and fertilizer on spotted knapweed and residual grass.

\section{Materials and Method}

\section{Study Sites}

Field studies were conducted during 1994 and 1995 on 3 sites in western Montana to evaluate the effect of combining picloram and fertilizer to control spotted knapweed and enhance grass yield. Study sites 1 and 2 were located near Bozeman, Mont. $\left(111^{\circ} 5^{\prime} 36^{\prime \prime} \mathrm{W}, 45^{\circ} 36^{\prime} 26^{\prime \prime} \mathrm{N}\right)$ and were adjacent to one another. Site 3 was located $30 \mathrm{~km}$ west of Ronan, Mont. (114 $20^{\prime} 0^{\prime \prime} \mathrm{W}$, $\left.47^{\circ} 2^{\prime} 06^{\prime \prime} \mathrm{N}\right)$. All sites were within a bluebunch wheatgrass (Pseudoroegneria spicata (Pursh) Scribn. \& Smith)-Idaho fescue habitat type (Daubenmire 1970), and were dominated by spotted knapweed. 
Site 1 was an abandoned hayfield. Spotted knapweed densities were 470 plants $\mathrm{m}^{2}(\mathrm{SD}=140)$. The residual grass understory was co-dominated by 2 introduced species, smooth bromegrass (Bromus inermis Leys) and timothy (Phleum pratense L.). The understory on Site 2 was dominated by the invader, Kentucky bluegrass (Poa pratensis L.). Spotted knapweed density was 140 plants $\mathrm{m}^{-2}(\mathrm{SD}=107)$. The soil, a complex consisting of $70 \%$ Beaverton cobbly loam (loamy-skeletal over sandy or sandyskeletal, mixed, Typic Argiborolls) and 30\% Hyalite loam (fineloamy, mixed, Typic Argiborolls) had zero slope and an elevation of $1,340 \mathrm{~m}$. Annual precipitation ranges from 381 to $483 \mathrm{~mm}$ and the frost-free period ranges from 90 to 110 days. Precipitation during 1994 and 1995 was 451 and $447 \mathrm{~mm}$, respectively.

The understory on site 3 was dominated by cheatgrass (Bromus tectorum L.), Canada bluegrass (Poa compressa L.) and Kentucky bluegrass. Spotted knapweed density was 420 plants $\mathrm{m}^{-2}$ $(\mathrm{SD}=142)$. Compared to sites 1 and 2 , site 3 was severely degraded. The soil at this study site was a Dryfork-Selow silt loam (coarse-silty, mixed, frigid Calcixbrollic Xerochretts) with zero slope. Annual precipitation ranges from 254 to $356 \mathrm{~mm}$. Precipitation during 1994 and 1995 was 321 and $280 \mathrm{~mm}$, respectively. The frost-free period ranges from 120 to 150 days.

\section{Experimental Design}

Sixteen treatments ( 4 picloram rates, 4 fertilizer rates) were applied to 4 by $4 \mathrm{~m}$ (site 1 and 2) or 6 by $6 \mathrm{~m}$ (site 3) plots and factorially arranged in a randomized-complete-block design. The experiment was replicated 4 times at each site. Picloram rates of $0.0,0.14,0.28$, and $0.42 \mathrm{~kg} \mathrm{ha}^{-1}$ were applied in the spring of 1994 using a 6 nozzle backpack sprayer (site 1 and 2) or a 6 nozzle 4-wheel ATV (site 3) delivering 130 liters/ha spray solution. Granular fertilizer was broadcast at $\mathrm{N}+\mathrm{P}$ rates of $0.0+0.0$, $10.5+13.2,21.1+26.4$, and $31.7+39.6 \mathrm{~kg} \mathrm{ha}^{-1}$ (source: $16-20-0, \mathrm{~N}-$ P-K; material: $0.0,66,132,198 \mathrm{~kg} \mathrm{ha}^{-1}$ ) using a hand-cyclone applicator. Sites 1 and 2 were treated on May 2, 1994. Air temperature, soil temperature (surface), and relative humidity were $15.5^{\circ} \mathrm{C}, 21^{\circ} \mathrm{C}, 58 \%$, respectively at the time of application. Winds were calm $\left(<5 \mathrm{~km} \mathrm{hr}^{-1}\right)$. Site 3 was treated on May 13, 1994. Air temperature, soil temperature (surface), relative humidity, were $17.5^{\circ} \mathrm{C}, 21^{\circ} \mathrm{C}$, and $90 \%$, respectively at the time of application. Winds ranged from 0 to $6 \mathrm{~km} \mathrm{hr}^{-1}$. Individual plots were spatially separated from each other by a $2.1 \mathrm{~m}$ buffer zone treated with $0.28 \mathrm{~kg} \mathrm{ha}^{-1}$ picloram to prevent spotted knapweed seed contamination from neighboring plots. Spotted knapweed was in the rosette growth stage at this time.

\section{Sampling}

At peak standing crop (August), above-ground grass biomass within a $1 \mathrm{~m}^{2}$ frame was harvested from each plot in both 1994 and 1995 . Grass samples were dried at $60^{\circ} \mathrm{C}$ until weights were constant and then weighed. Spotted knapweed density (plants $\mathrm{m}^{-2}$ ) was counted in two $0.1 \mathrm{~m}(2 \times 5 \mathrm{dm})$ Daubenmire (1970) frames at each site at the time of harvest.

\section{Data Analysis}

Data were first analyzed with multiple linear regression (least squares) models using picloram and fertilizer as independent variables. Scatterplots of the residual versus the standardized predicted values indicated that most of the data did not fit a linear model. Therefore, all data were analyzed using standard analysis of variance procedures.

Each site was analyzed separately. The model used was a splitplot in time with herbicide, fertilizer, and herbicide $\times$ fertilizer as the wholeplots. Wholeplots were tested using the pooled mean square of block $\times$ herbicide, block $\times$ fertilizer, and block $\times$ herbicide $x$ fertilizer as the error term. Year, year $\times$ herbicide, year $x$ fertilizer, and year $x$ herbicide $x$ fertilizer were included in the subplot analysis. Subplots were tested using the pooled mean square of year $\times$ block, year $\times$ block $\times$ herbicide, year $\times$ block $\times$ fertilizer, and year $\times$ block $\times$ herbicide $\times$ fertilizer as the error term. When a significant $(P<0.05)$ F-test was calculated, differences among means were tested using least significant differences procedures.

\section{Results and Discussion}

Analysis of variance shows picloram and fertilizer did not interact to affect either grass yield or spotted knapweed density (Table 1). On site 1 (smooth bromegrass/timothy) and site 3 (cheatgrass), the effect of picloram on spotted knapweed density and grass yield was dependent on year. On these sites, spotted

Table 1. Model components, degrees of freedom (df) and mean squares for grass yield (Gyd) and spotted knapweed density (Skn).

\begin{tabular}{|c|c|c|c|c|c|c|c|}
\hline \multirow[t]{3}{*}{ Component } & \multirow[t]{3}{*}{$\overline{\text { df }}$} & \multicolumn{6}{|c|}{ Mean square } \\
\hline & & \multicolumn{2}{|c|}{ Site I } & \multicolumn{2}{|c|}{ Site 2} & \multicolumn{2}{|c|}{ Site 3} \\
\hline & & Gyd & Skn & Gyd & Skn & Gyd & Skn \\
\hline Herbicide & 3 & $19,482,625^{*}$ & $3,060,953^{*}$ & $2,519,947^{*}$ & $148,292^{*}$ & $10,316,317^{*}$ & $448,378^{*}$ \\
\hline Fertilizer & 3 & $3,513,076^{*}$ & 28,165 & $665,041 * *$ & 7,172 & $1,585,529 * *$ & 1,705 \\
\hline Herbicide $\mathrm{x}$ fertilizer & 9 & 568,976 & 30,083 & 299,061 & 7,182 & 780,418 & 856 \\
\hline Whole plot error & 45 & 623,998 & 45,355 & 248,490 & 7,028 & 683,886 & 4,884 \\
\hline Year & 1 & $59,430,519^{*}$ & $409,635^{*}$ & $16,891,634^{*}$ & 1,070 & $87,321,086^{*}$ & $243,315^{*}$ \\
\hline Year $\mathrm{x}$ herbicide & 9 & $3,345,441^{*}$ & $489,601^{*}$ & 616,418 & 1,273 & $8,651,164^{*}$ & $214,590^{*}$ \\
\hline Year $x$ fertilizer & 9 & 466,457 & 36,390 & 532,832 & 1,026 & $1,826,007^{*}$ & 747 \\
\hline Year $\mathrm{x}$ herbicide $\mathrm{x}$ fertilizer & 27 & 280,330 & 43,437 & 252,428 & 928 & 806,931 & 284 \\
\hline Subplot error & & 419,600 & 50,845 & 374,732 & 2,003 & 713,823 & 5,216 \\
\hline Subplot df & & 47 & 47 & 48 & 48 & 48 & 48 \\
\hline
\end{tabular}

*,** significant at the $5 \%$ and $10 \%$ levels of probability, respectively. 


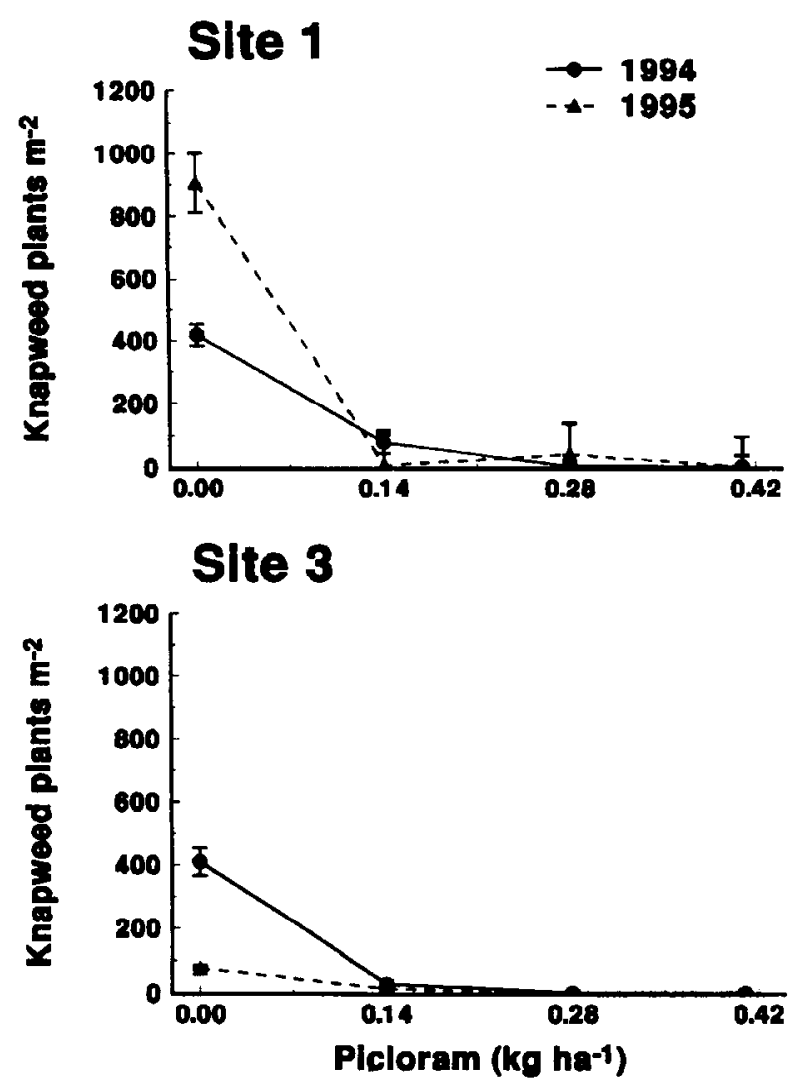

Fig. 1. Effect of year by picloram on spotted knapweed density (plants $\left.\mathrm{m}^{-2}\right)^{1}$ on site 1 (smooth bromegrass/timothy) and site 3 (cheatgrass). 'Error bars represent \pm 1SE.

knapweed density in plots without picloram were affected by year, which accounted for the interaction (Fig. 1). All picloram treatments reduced spotted knapweed density equally on all 3 sites (Figs. 1 and 2).

In 1994, picloram increased grass yield over those treatments without the herbicide on sites 1 (Fig. 3) and 2 (Fig. 4), but not on site 3 (Fig. 3). On site 3, we believe that cheatgrass, Kentucky bluegrass, and Canada bluegrass were suppressed to the point where they were unable to respond to knapweed control that year. In addition, the early maturing cheatgrass may have completed its life-cycle before it could benefit from knapweed control.

By 1995, picloram increased grass yield on all sites (Figs. 3 and 4). On sites 1 and 3, those plots treated with picloram had lower grass yield in 1994 than in 1995. In all cases, increasing picloram rate had no effect on grass yield.

In Montana, the current recommended rate for controlling spotted knapweed using picloram is $0.28 \mathrm{~kg} \mathrm{ha}^{-1}$ (Fay et al. 1995). In an 8 year study, Davis (1990) found $0.14 \mathrm{~kg} \mathrm{ha}^{-1}$ provided $100 \%$ spotted knapweed control for at least 3 years, and provided similar control and grass yield to that of picloram at higher rates $\left(0.22,0.25\right.$, and $\left.0.28 \mathrm{~kg} \mathrm{ha}^{-1}\right)$ throughout the study. Effective long-term control of spotted knapweed requires periodic applications of picloram which are only cost-effective on highly productive range sites with a substantial grass understory (Griffith and Lacey 1991). Using the $0.14 \mathrm{~kg} \mathrm{ha}^{-1}$ picloram rate may allow landowners a more cost-effective spotted knapweed control pro-
Site 2

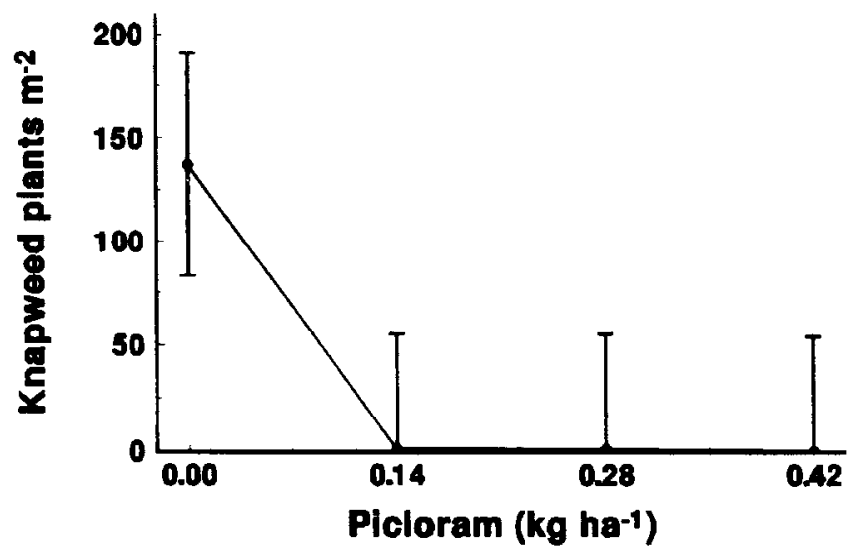

Fig. 2. Main effect of picloram on spotted knapweed density (plants $\left.\mathrm{m}^{-2}\right)^{\mathrm{x}}$ on site 2 (Kentucky bluegrass). ${ }^{1}$ Error bars represent \pm 1 1SE.

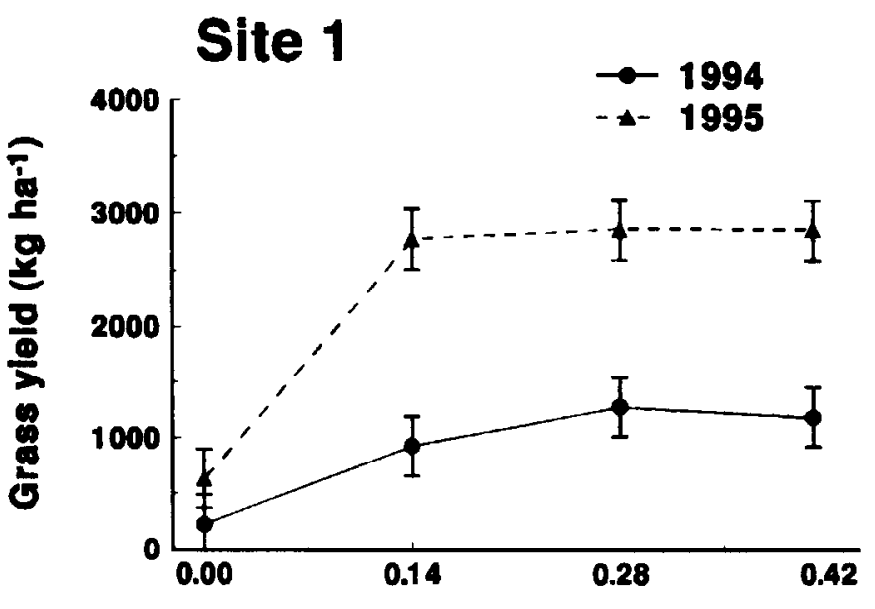

Site 3

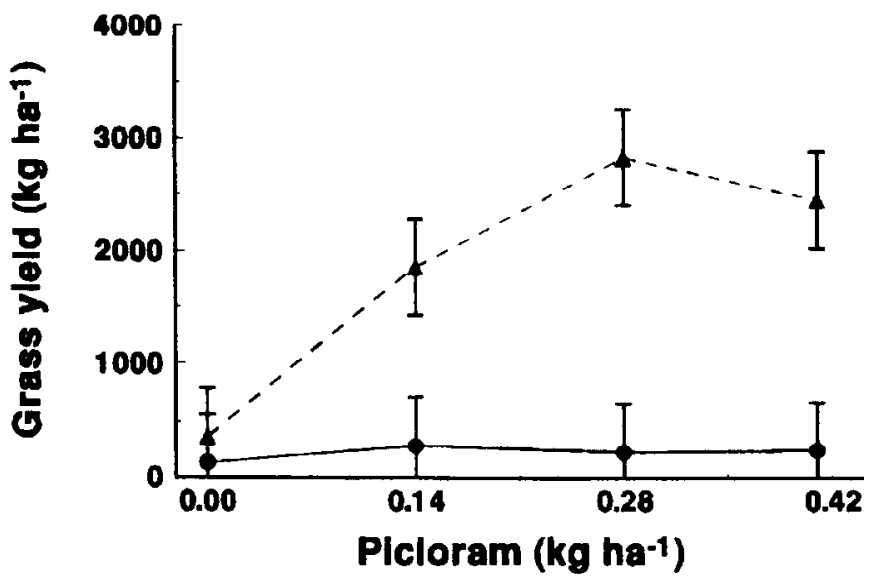

Fig. 3. Effect of year by picloram on grass yield $\left(\mathrm{Kg} \mathrm{ha}^{-1}\right)^{1}$ on site 1 (smooth bromegrass/timothy) and site 3 (cheatgrass). 'Error bars represent \pm 1SE. 


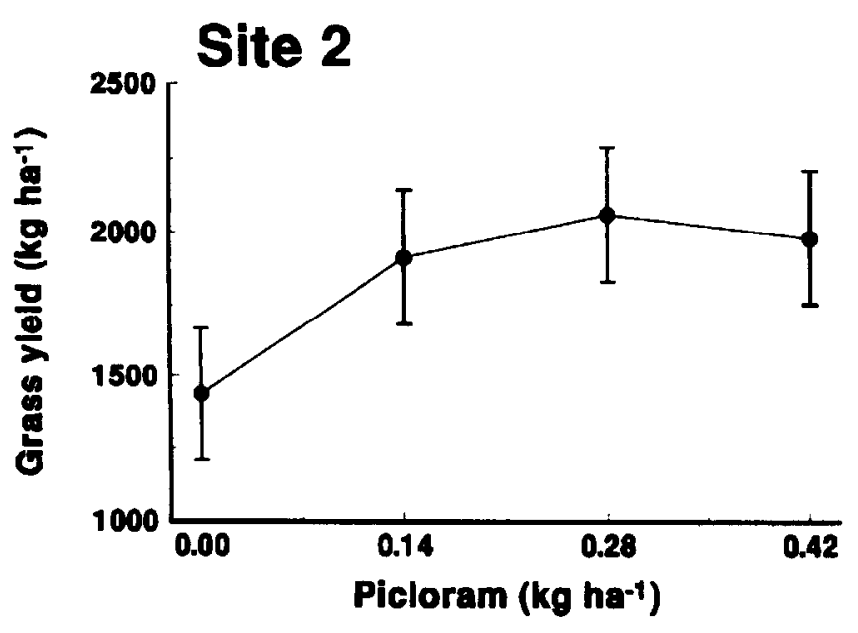

Fig. 4. Main effect of picloram on grass yield $\left(\mathrm{Kg} \mathrm{ha}^{-1}\right)^{1}$ on site 2 (Kentucky bluegrass). ${ }^{1}$ Error bars represent \pm 1 ISE.
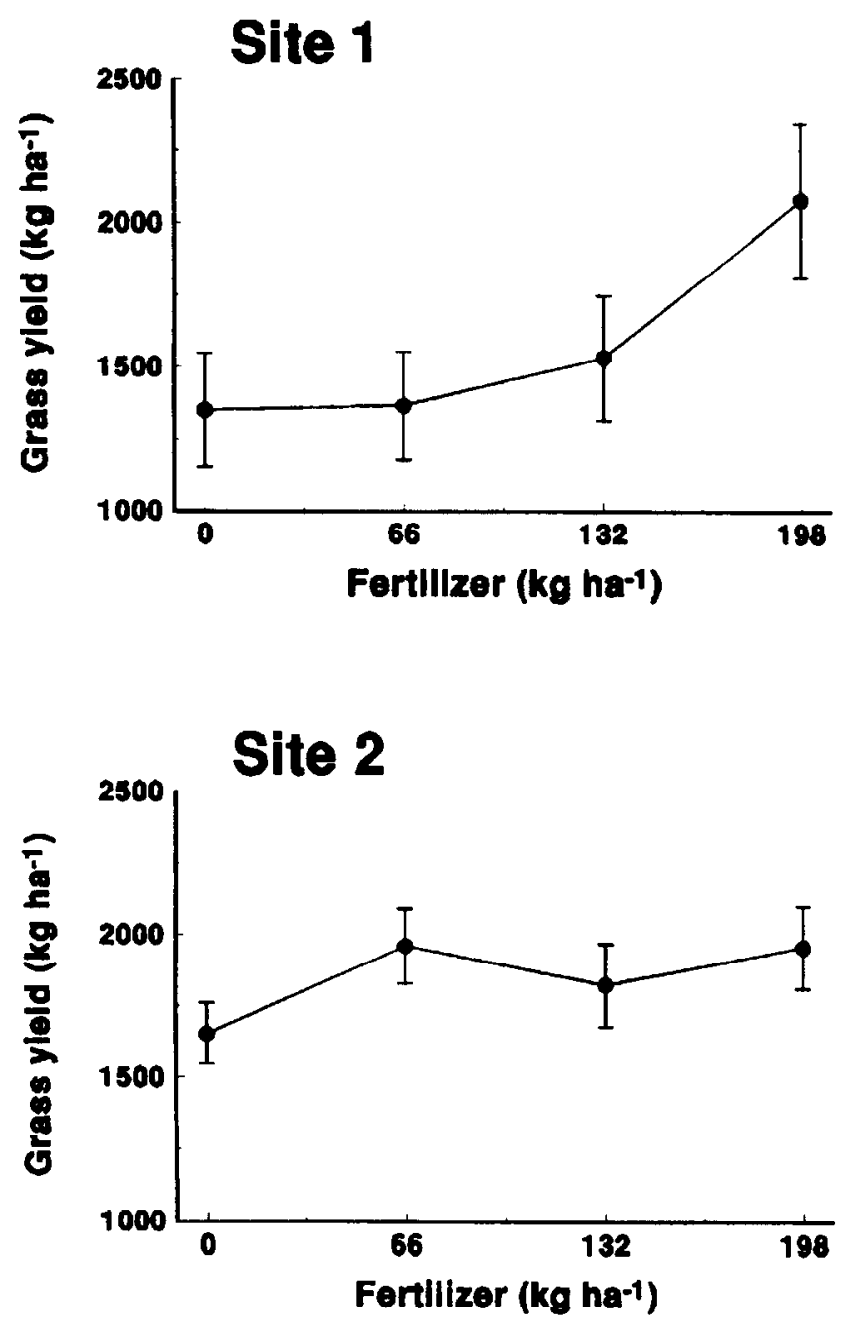

Fig. 5. Main effect of fertilizer (material: $0.0,66(10.5 \mathrm{~N}+13.2 \mathrm{P}), 132$ (21.1N+26.4P), $198(31.7 \mathrm{~N}+39.6 \mathrm{P}) \mathrm{kg} \mathrm{ha}$; source: $16-20-0 \mathrm{~N}-\mathrm{P}-\mathrm{K})$ on grass yield (kg ha-1) ${ }^{1}$ on site 1 (smooth bromegrass/timothy) and site 2 (Kentucky bluegrass). ${ }^{1}$ Error bars represent \pm 1 SE.

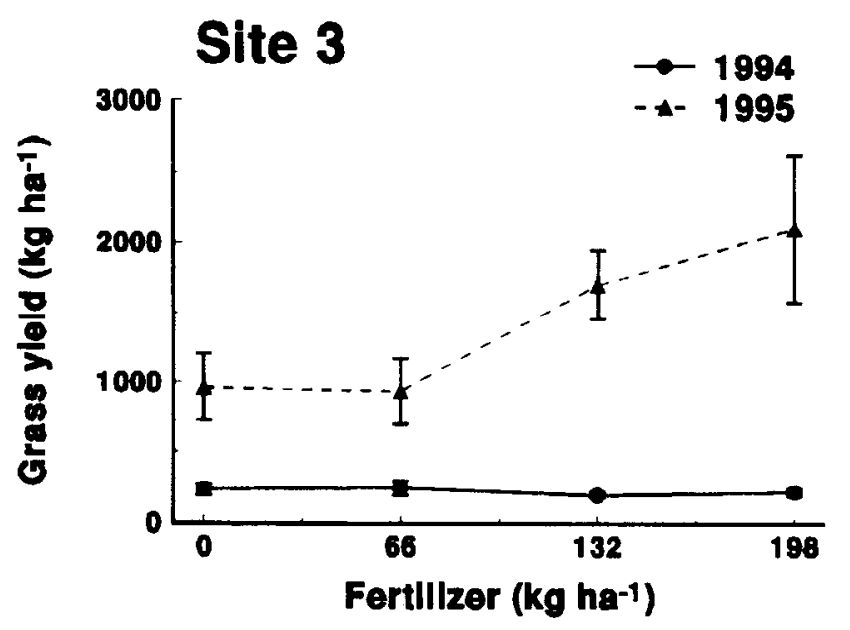

Fig. 6. Efiect of year by fertilizer (material: $0.0,66(10.5 \mathrm{~N}+13.2 \mathrm{P})$, $132(21.1 \mathrm{~N}+26.4 \mathrm{P}), 198(31.7 \mathrm{~N}+39.6 \mathrm{P}) \mathrm{kg} \mathrm{ha}^{2}$; source: $16-20-0 \mathrm{~N}-$ $\mathrm{P}-\mathrm{K}$ ) on grass yield (kg ha-1)' on site 3 (cheatgrass). ' Error bars represent \pm 1SE.

gram on marginally productive range sites. However, we believe that picloram applications must be carefully timed with plant phenology and weather conditions to ensure adequate control at this reduced rate.

Fertilizer had no effect on spotted knapweed density (Table 1). Fertilizer (main effect) increased grass yield on sites 1 and 2 (Fig. 5). On site 1 , only $\mathrm{N}+\mathrm{P}$ applied at $31.7+37.6 \mathrm{~kg} \mathrm{ha}^{-1}$ increased grass yield. Fertilizer applied at N+P rates of $10.5+13.2$ and $31.7+39.6 \mathrm{~kg} \mathrm{ha}^{-1}$ slightly increased grass yield over those treatments without these chemicals on site $2(\mathrm{P}=0.1)$. All fertilizer rates other than zero produced similar grass yield on that site. Similar results were obtained by Sheley et al. (1984) in Idaho.

On site 3, which was dominated by cheatgrass, the effects of fertilizer was dependent on year (Table 1). Grass yield was unaffected by fertilizer in 1994. In 1995, N+P rates of $21.1+26.4$ and $31.7+39.6 \mathrm{~kg} \mathrm{ha}^{-1}$ increased grass yield over $0.0+0.0$ and $10.5+13.2 \mathrm{~kg} \mathrm{ha}^{-1}$ (Fig. 6).

Although fertilizer did not interact with picloram to enhance grass yield, high rates substantially increased grass yield on the smooth bromegrass/timothy and cheatgrass sites. Sheley and Roché (1982) found an interaction between picloram and fertilizer, resulting in both greater spotted knapweed control and grass production. However, that study was conducted on an abandoned hayfield receiving about $762 \mathrm{~mm}$ of precipitation annually. If the increased grass yield indicates increased competitiveness, spotted knapweed reinvasion should be slowed. Managing for increased forage production combined with longer knapweed control could be cost-effective in some situations.

\section{Literature Cited}

Chicoine, T.K. 1984. Spotted knapweed (Centaurea maculosa L.) control, seed longevity and migration in Montana. M.S. Thesis. Montana State Univ. 83 pp.

Chicoine, T.K., P.K. Fay, and G.A. Nielsen. 1985. Predicting weed migration from soil and climate maps. Weed Sci. 34:57-61. 
Daubenmire, R. 1970. Steppe vegetation of Washington. Washington Agr. Exp. Sta. Tech. Bull. No. 62.

Davis, E.S. 1990. Spotted knapweed (Centaurea maculosa L.) seed longevity, chemical control and seed morphology. M.S. Thesis. Montana State Univ. 109 pp.

Dwyer, D.D. and J.G. Schickendanz. 1971. Vegetation and cattle response to nitrogen-fertilized rangeland in south-central New Mexico. New Mexico State Univ. Agr. Exp. Sta. Res. Rep. 215:1-5.

Fay, P.K., E.S. Davis, T.B. Chicoine, and C.A. Lacey. 1989. The status of long term chemical control of spotted knapweed. Proc. Knapweed Symp. Montana State Univ., Plant and Soil Sci. Dept. and Coop. Ext. Serv., Bozeman, Mont. pp.43-46.

Fay, P., T. Whitson, S. Dewey, and R. Sheley (eds./authors). 1995. 1995-96 Montana-Utah-Wyoming Weed Management Handbook. Montana State Univ. Coop. Ext. Serv. Bull. EB23. 245 pp.

Griffith, D. and J.R. Lacey. 1991. Economic evaluation of spotted knapweed (Centaurea maculosa) control using picloram. J. Range Manage. 44:42-44.

Hamaker, J.W., C.R. Youngson, and G.A. Goring. 1967. Predictions of the persistence and activity of Tordon herbicide in soils under field conditions. Down to Earth. 23:30-36.

Hart, R.H., M.C. Shoop, and M.M. Ashby. 1995. Nitrogen and atrazine on shortgrass: Vegetation, cattle and economic responses. J. Range Manage. 48:165-171.

Hubbard, W.A. 1975. Increased range forage production by reseeding and the chemical control of knapweed. J. Range Manage. 28:406-407.
Lacey, C.A. 1985. A weed education program, and the biology and control of spotted knapweed (Centaurea maculosa Lam.) in Montana. M.S. Thesis, Montana State Univ. 179 pp.

Lacey, J.R., C.B. Marlow, and J.R. Lane. 1989. Influence of spotted knapweed (Centaurea maculosa) on surface runoff and sediment yield. Weed Technol. 3:627-630.

Roché, B.F. 1988. Management technologies for diffuse knapweed control. Knapweed. 1:4.

Roché, B.F., Jr. and C.J. Talbott. 1986. The collection history of Centaurea found in Washington state. Agr.. Res. Center Res. Bull. XB0978. Wash. State Univ. Coop. Ext. Pullman, Wash. 36 pp.

Sheley, R.L. and B.F. Roché, Jr. 1982. Rehabilitation of spotted knapweed infested rangeland in northeastern Washington. Abstr. of papers, W. Soc. Weed Sci., Denver, Colo.

Sheley, R.L., R.H. Callihan, and C.H. Huston. 1984. Improvement of spotted knapweed-infested pasture with picloram and fertilizer. Montana State Univ. Coop. Ext. Bull. 1315. pp. 21-22.

Spoon, C.W., H.R. Bowles, and A. Kulla. 1983. Noxious weeds on the Lolo National Forest. USDA Forest Serv., Northern Region, Situation Analysis Staff Paper. Missoula, Mont.

Tyser, R.W. and C.H. Key. 1988. Spotted knapweed in natural area fescue grasslands: An ecological assessment. Northwest Sci. 62:151-160.

Watson, A.K. and A.J. Renney. 1974. The biology of Canadian weeds. Centaurea diffusa and C. maculosa. Can. J. Plant Sci. 54:687-701. 